\title{
Now Let Us Make Europeans - Citizenship, Solidarity and Identity in a Multicultural Europe
}

\author{
Pablo Cristóbal Jiménez Lobeira ${ }^{1}$
}

\begin{abstract}
The euro crisis has hit "Europe" (the European Union, or EU) at its root. Economic harshness, social unrest and political turmoil betray a deeper problem: $a$ weak pan-European sense of belonging - a common political identity thanks to which European citizens may regard each other as equals, and therefore as deserving of recognition, trust, and solidarity. This paper explores interculturalism from an analogical perspective, looking at the harmonious interplay between human rights and cultural plurality, as a possible source of trust and solidarity among European citizens. Only a common - even if analogical - political identity, whereby European citizens regard each other, if not as "siblings" at least as "cousins," can make the sacrifices required to overcome the crisis meaningful and therefore less unlikely to happen.
\end{abstract}

Keywords: Analogical hermeneutics, interculturalism, human rights, solidarity, euro crisis, European citizens, political identity

It is attributed to Massimo Taparelli, marquis of Azeglio, a painter, writer, politician and patriot of the Risorgimento-Italy's unification-and member of the first Italian Parliament (1861), the famous sentence: "Italy has been made, now we must make Italians."2 At least a clear idea of what Italy was, existed: a unified nation with the regime of a constitutional monarchy. A century and a half later another union (with continental pretence) strives for survival, though nobody knows for certain what kind of regime it has, and there is little evidence that an appetite for the creation of a demos exists, since it is made of very different nations. This entity, in the words of Ivan Krastrev "the most sophisticated political puzzle that history has known,"3 is the EU. And as the second decade of the XXI century unfolds, the project faces its most formidable challenges since its foundation.

In what follows this paper will submit that the present crisis, with evident economic manifestations, has deeper, political and cultural roots, which should be considered seriously if the EU, which rightly must be regarded as a sui generis polity, is to advance into the future keeping its rare mixture of unity and diversity, of intergovernmentalism and mild federalism, of multinational colour and 


\section{Now Let Us Make Europeans}

transnational cooperation, of distinctive regional idiosyncrasies and a weak but real (or analogical) identity and solidarity.

\section{One citizenship, many citizens}

On Thursday May 312012 Thomas Steffen, a director general in the German ministry of finance caused a stir in Brussels at a conference organised by the European Commission. In response to the suggestion by Italy's Prime Minister Mario Monti, that Germany was been too slow to help indebted countries in the eurozone, Steffen urged such countries to turn from "grasshoppers" who enjoyed the summer spending a lot of money," into "ants" who worked instead during summer preparing for winter. "Maybe we should all become ants rather than grasshoppers" he reportedly said. ${ }^{4}$

Phillippe Aghion, a French economist based at Harvard University, suggested for the present crisis a different fable from the same author (Jean de La Fontaine): that of the oak despising the bamboo's flexibility, until a storm comes and the first one breaks but the second survives. Steffen retorted that it was "not a German oak". He compared the "southern" (mainly Mediterranean) euro zone countries with East Germany during the reunification process, where huge amounts of money invested have still not had satisfactory results. ${ }^{5}$

Germany has, indeed, poured the equivalent of around 2 trillion US dollars into its former East along more than 20 years, with only mixed results (great disparities still prevail). ${ }^{6}$ And in Berlin's view larger disbursements on troubled countries like Greece (Portugal, Spain, Italy) should come accompanied of incentives for midsize companies, loosening of protections against firing for workers, special economic zones, selling of state-owned enterprises, and even a version of Germany's dual system of training (in vocational schools, and handson work at companies). ${ }^{7}$

Unthinkable as it was only a few months ago, by the middle of 2012 top EU officials are sending alarm signals publicly that something had to be done soon to fight the crisis. Olli Rehn, vice-president of the European Commission and Commissioner for Economic and monetary affairs and the Euro, warned that the single currency area could disintegrate without stronger crisis-fighting mechanisms and tough fiscal discipline. ${ }^{8}$ The collapse of the euro could be catastrophic for the former euro zone, with first-year output losses of nearly 9\%; even Germany's GDP could drop over $8 \%$ as exporters contended with the strength of a reborn D-mark. ${ }^{9}$

Even more disturbingly, Mario Draghi said that the European Central Bank (which he heads) could not "fill the vacuum left by member states' lack of action." European leaders, he added, had to decide whether to stand by the eurozone: "the sooner the vision is clarified the better for the European Union". ${ }^{10}$ Bank of Italy governor (and member of the ECB's governing council) Ignazio Visco, 


\section{Citizenship, Solidarity and Identity}

pointed out that political inertia and bad economic decisions had put "the entire European edifice" at risk and only a clear path to political union could save the euro. ${ }^{11}$

What steps are needed to address this profound crisis? The first and most evident one is a series of sensible economic measures. Suggestions abound. We will mention a few to illustrate. But as we shall see later on, the economic aspect is only an initial step of a much more complex solution.

\section{A $\lambda \lambda \eta \lambda \varepsilon \gamma \gamma \sigma \eta$ : Greek for solidarity}

Nobel Prize-winning economist Paul Krugman believes that with some adjustments (looser monetary policy, tolerance to possible short-term increase in inflation, open-ended lending to governments and banks) the crisis can be averted. ${ }^{12}$ It has become clear from the situations not only in Greece (which owes euro area governments and institutions an equivalent of $3 \%$ of the zone's GDP) ${ }^{13}$ but notably in Spain (the fourth largest economy after Germany, France and Italy), that the present remedies are insufficient and more vigorous-and above all more coordinated-action is required.

Thus a recent "Recommendation" made by the Council of the EU underscores the need for fiscal discipline, "growth-friendly expenditure," the correction of macroeconomic imbalances not only on the part of indebted member states but also with participation from "surplus countries" (eminently Germany), as well as financial integration, to ensure also "an adequate flow of credit to the real economy. ${ }^{14}$

Several analysts suggested that, since the euro zone's problem is not its debt size but its fragmented structure, some sharing of the burden and some ceding of sovereignty by all of the euro zone countries could tackle the difficulties successfully. Compared with over $100 \%$ in the US, the eurozone public debt is less than $90 \%$ of GDP. ${ }^{15}$ Concretely, they propose to "fill in two holes in the single currency's original design." First, to create a euro-zone, supranational system of "supervision, recapitalisation, deposit insurance and regulation" for (at least the most important) banks. Second, to mutualise eurozone governments, at least that above $60 \%$ of GDP for any particular member country, to be paid over the next 25 years, therefore limited Eurobonds. ${ }^{16}$

Spain's deepening recession, with "drowning banks and soaring borrowing costs," a situation which sends alarm signals to the eurozone's third largest economy, Italy-it might eventually catch up with France as well—has brought to discussion the convenience of euro-zone countries collectively injecting funds directly into Spain's and eventually other countries' banks. ${ }^{17}$ Both the International Monetary Fund (IMF) and the ECB have expressed favourable views in the possibility, as Italian Prime Minister Monti has urged Germany to "reconsider its opposition to having common defences in order to shield 


\title{
Now Let Us Make Europeans
}

\author{
Italy and Spain from contagion." ${ }^{18}$
}

The idea of a "banking union" was also presented formally by the Commission, in order to break the vicious circle of weak banks and indebted governments, lending to each other..$^{19}$ In a document on "actions for stability, growth and jobs" the Commission details more measures to tackle the economic crisis, among which are the reinforcement of the Stability and Growth Pact and the financial backstops (for instance the European Stability Mechanism in force as of the $1^{\text {st }}$ July 2012), a stronger banking sector, a deepening of economic and monetary union, improvements to the EU patent and the Services Directive initiatives to liberalise internal markets and increase trade, empowering further the European Investment Bank, and others. ${ }^{20}$ But economic solutions require political agreements.

Chancellor Angela Merkel has been blamed for the fate of many a Greek, and for austerity and unemployment in battered countries across Europe, she has been caricatured as a fearless, steely Prussian, ${ }^{21}$ even as a Nazi, ${ }^{22}$ labelled as inflexible and stubborn. ${ }^{23}$ On closer inspection, however, the most important political leader of the EU is deeply concerned that "more Europe" from the economic point of view (fiscal and banking integration), implies more sacrifices from European citizens. Neither member state nor European authorities can just assume that their citizens are happy to undertake those sacrifices. The "democratic deficit" that had long worried the architects of integration (and some scholars) in times where "output legitimacy" sufficed for European citizens not to bother asking much, has become acute and must be addressed.

Ms Merkel is certainly a different kind of leader. Her natural sciences background certainly makes her cautious. She finds herself in an unsought position whereby she has to fight the economic crisis in Europe, please her Christian Democratic (CDU) party, and pay attention to the desires of Germans, for whom she continues to be incredibly popular (with $50 \%$ of her compatriots wanting her as Chancellor, even in the face of declining preferences for the CDU). ${ }^{24}$

On closer look, the most important political leader of the EU is deeply concerned that "more Europe" from the economic point of view (fiscal and banking integration), which implies more sacrifices from European citizens, both in terms of resources and of "national" (state) sovereignty contributed to a European, supra-member state level. Neither member state governments, nor European authorities can just assume that their citizens-who are also "European" (EU) citizens-are happy to undertake those sacrifices. The "democratic deficit" that had long worried the elites architects of integration (and some scholars) in times where "output legitimacy" sufficed for European citizens not to bother asking much, has become acute in the most difficult situation, and must be addressed. Or so Ms Merkel thinks. On a 


\section{Citizenship, Solidarity and Identity}

speech in Berlin, to mark the $20^{\text {th }}$ anniversary of the signing of the Maastricht Treaty, which among other elements created the EU, European citizenship, and laid the foundations for the euro, Merkel stressed that political union had not been done. In her vision the presidencies of the Council and of the Commission could be fused in one position, elected by popular vote across Europe; the Commission would work as the executive branch, the Council would become a second chamber (senate) of the Parliament, and the European Court of Justice the highest judicial authority. ${ }^{25}$

According to her team's vision, the "fiscal compact" to introduce budgetary discipline is only a first step. The second step would consist of tax and spending priorities harmonised by the commission and all eurozone finance ministers. Eurobonds could be accepted then. Because of the importance of these changes, Ms Merkel wants to see the "dangerous disconnection between national politics and national parliaments, and the European Parliament," addressed, as the only way in which the monetary union can survive. ${ }^{26}$ In fact, her style of leadership apart, she may have a point, a point especially and increasingly important for ordinary European citizens.

Objections to more spending in order to promote growth, for instance, require the acquiescence of those who have paid in taxes the euros about to be spent. Since the beginning of the euro crisis 17 member state leaders have been ejected from office. ${ }^{27}$ With no way to influence Brussels directly, European citizens have voted against incumbents nationally, and shifted preferences to fringe and sometimes radical parties. The European Parliament has, if anything

...widened the deficit it is meant to make up. It has increased its powers with every EU treaty, including the fiscal compact; but it has seen no parallel growth in its legitimacy. In the commission and in national capitals alike, frustration with the parliament has been growing. It is almost always in favour of more spending. ${ }^{28}$

At every election the turnout across (from just above 60\% in 1979) the continent has plumbed (to under $45 \%$ in 2009). Fringe parties, which have been doing well in member state elections, do even better in votes for Strasbourg. ${ }^{29}$ An alternative could be in greater participation of national parliaments at a European level.

Ms Merkel wants to see the "dangerous disconnection between national politics and national parliaments, and the European Parliament," addressed, as the only way in which the monetary union can survive. ${ }^{30}$ In fact, her style of leadership apart, she may have a point, a point especially and increasingly important for ordinary European citizens. Since the beginning of the euro crisis 17 member state leaders have been ejected from office. ${ }^{31}$ With no way to influence Brussels directly, European citizens have voted against incumbents 


\section{Now Let Us Make Europeans}

nationally, and shifted preferences to fringe and sometimes radical parties. At every election for the European Parliament the turnout across the continent has plumbed (from just above 60\% in 1979 to under 45\% in 2009). Fringe parties, which have doing well in member state elections, do even better in votes for Strasbourg. ${ }^{32}$ An alternative could be in greater participation of national parliaments at a European level.

Elsewhere I have tried to address the problem of political integration suggesting that Europe does not have a demos, rather demoi, and that an analogical polity is not only a feasible-if hybrid and complex-solution, but also more desirable due to the specificity of Europe, its rich multi-national diversity, and the wish-or tolerance-of Europeans to only a certain degree of integration. ${ }^{33}$ This has been characteristic of the European project right from the start. ${ }^{34}$

Yet what can be the ground for such hybrid, or "analogical" integration? If it is true that political union can create some common identity, it is also true that at least some cultural affinity predisposes and enables the existence of a polity. ${ }^{35}$ However the source of political unity, the common identity requires a weaker, analogical character, whereby European citizens can relate to each other with some level of closeness, even though much less than the closeness that exists between compatriots. ${ }^{36}$

One condition for the emergence of a common political identity is an open an inclusive public sphere that allows European citizens to discuss and participate in the construction and life of the polity, allowing for their cultural differences to be taken into account inasmuch as possible. ${ }^{37}$ Yet an open space that excludes no one is still not enough. Beyond pure tolerance, it involves recognition, interrelation and intercultural exchange. Let us investigate this further.

\section{The source of solidarity: political identity}

The fabled controversy about ants and grasshoppers, oaks and bamboos, which occurred recently not in the kindergarten of a remote European town, but among high ranking officials and scholars at the headquarters of the European Union in Brussels, is very telling. The crisis, Anton La Guardia remarks, "has confirmed countries in their prejudices. ${ }^{38}$ He continues:

Germans see Greeks as indolent and corrupt; do they really want to commit the German checkbook to Greece fully and indefinitely? And having portrayed Angela Merkel and Wolfgang Schaube as the embodiment of the old Nazi invader, are Greeks ready to be forever bound to German strictures? ${ }^{39}$

Sharing burdens and giving up more sovereignty, even if in a controlled, limited way, requires the implementation of greater integration. But both, economic and political integration imply a sense of solidarity, of common political ("European") identity that justifies at least moderate sacrifices being 


\section{Citizenship, Solidarity and Identity}

made for each other. Michael Burda considers that "The limit of German brotherhood extended to East Germany," and Germans "saw what happened with two trillion euros over the past 20 years. And these are people they love. They don't consider the Greeks their brothers." ${ }^{40}$

Yet clichés are not patented to Greeks and Germans alone. Europe is a region of the world in which many national groups have defined themselves, for centuries, at least partially in reference to "the other" next door who is not "like us". Unfortunately (or, if it brings them consolation, fortunately) clichés are not patented to Greeks and Germans alone. Europe is a region of the world in which many national groups have defined themselves, for centuries, in part in reference to "the other" next door who is not "like us". It happens between Croatians and Slovenians, between Poles and Germans, ${ }^{41}$ between Lithuanians and Poles, between Swedish and Fins, between Slovaks and Czechs, between Spaniards and Portuguese,... It is not even necessary to leave a member state to find prejudices about "others," one just have to think of the differences between Bavarians and Prussians in Germany, between Walloons and Flemish in Belgium, between Andalusians and Gallicians in Spain, between Sardinians and Friulians in Italy, and so forth.

However the reality is more complex. Europeans do find some similarities with each other when they are abroad, say in Africa or Asia. For all their differences, they usually like to think of themselves as not the same as (even if often in sympathy with) Americans. When they work at supra-state institutions (e.g. the EU, or the Council of Europe), participate in student mobility programs like Erasums, or express conceptions of culture and life-style (ideas about, and attitudes towards food, history, the economy, the state), they find themselves less far from each other than they thought they were. Using Mr Burda's image above, they may not perceive themselves as siblings, but perhaps as "cousins" or "distant relatives," someone they know either because they have done business together, because geography has made them visit each other often, or even because they have fought wars against each other several times along the centuries.

One very concrete part of European culture with which few EU citizens would disagree is the importance of human rights as they are known today. Concrete contemporary expressions of the concept are given by the European Convention of Human Rights, ${ }^{42}$ and more recently by the Charter of Fundamental Rights of the EU. ${ }^{43}$ If solidarity (even a mitigated one because it is trans-statal across Europe) is to operate from one member state to the other, from one region to the next, from one European citizen to another, there has to be something they can feel as possessing in common, ${ }^{44}$ something that identifies them as part of the same political community, even if such political community being a collection of states, is not itself a state. A common identity that makes the other 27 member states (if we include the newest, Croatia), and especially the other 16 eurozone countries, see with concern the problems Greece is facing at least to a 


\section{Now Let Us Make Europeans}

certain extent as their own. ${ }^{45}$

In a very interesting comparative analysis between the collapse of the Soviet Union and the present predicament of the EU, Krastev expresses astonishment before "the horrifying inability of the southern debt-ridden countries to 'translate' their concern into German," and at the "growing failure of Germany to "translate its proposed solutions into the local languages of most of the other member states." The problem is not, in his view, one of diverging interests, but rather of "lack of empathy." 46

And empathy, that capacity to "enter" into not only what the other "feels" but also what happens to her and the way she experiences it, certainly facilitates solidarity. In order to understand the other in that way, with empathy, some perceived commonalities help. Not comprehensive commonalities perhaps, but at least those that permit solidarity at the level of a broad political community, as is the case of the EU. Thus we can speak of (common) political identity as that atmosphere that allows solidarity.

In order to come to existence, political identity requires some material elements that are substantive-for instance the familiar political culture of human rights-and others that are formal-as is an open and inclusive public sphere, that sets an atmosphere for dialogue. But it also requires active elements that realise, build and renew the collective identity of the political community. One of them is relationality, which operates through intercultural exchange.

\section{Identity, analogical hermeneutics, interculturalism}

To be clear, I am not suggesting that the instant solution to the present economic crisis in Europe is interculturalism. As has been shown above, the problems are very specific and demand adequate (and urgent) action. Yet it is also clear that economic solutions require political decisions, and in democratic polities-like every single member state of the EU-those decisions require legitimacy-the mandate or at least assent-of the citizens. But such assent becomes a difficult issue because European citizens can hardly see themselves as part of the same community, as "political siblings," in the way in which they, arguably, see compatriots in their own member state.

Interculturalism starts from the idea that culture is an undeniable aspect of being human, and therefore of human beings and human groups. Like multiculturalism, it agrees that cultural differences should be acknowledged in constitutional democracies, in order to ensure for culturally diverse individuals and groups some respect and tolerance, and to avoid explicit or implicit discrimination on the basis of those differences. But beyond multiculturalism, interculturalism suggests another step: that of the cultural interaction and exchange. Under a relational paradigm whereby I do not only respect the other but actually converse with him, learn from him appreciate him in what he is - also 


\section{Citizenship, Solidarity and Identity}

in his culture, and expect a similar attitude in return, the barriers of strict tolerance, which end up creating ghettos and even parallel societies, recede. ${ }^{47}$

One obstacle to this relational interaction is the absence of a common language. Krastev's image of Germans and Greeks not being able to "translate" into the language of the other their views and needs as the crisis continues to unfold and the EU is on the brink of collapse, is a powerful image. He was not, of course, speaking of literal translations from Greek to German and the other way around-a considerable amount of the EU's yearly budget is destined to pay for translations to its 23 (soon 24) official languages. But what can constitute that transcultural language that facilitates dialogue?

Among others, Mauricio Beuchot has suggested that such common ground could be constituted by the idea of human rights. ${ }^{48}$ His main concern is the problem of cultural plurality present in several Latin American countries, eminently in Mexico, where still today a mainstream Western culture, mainly come from Europe through Spain, must interact with many pre-Columbian indigenous cultures which have survived into the XXI century. ${ }^{49}$ The idea could be useful, a fortiori, in Europe, cradle of the modern conception of human rights.

They are a concept deeply enrooted in the culture of Europeans, a ground on which everybody roughly agrees. Greeks may not be siblings to Germans, but certainly they are a people who believes deeply, like Germans, in human rightseven claims to be one of the springs of European (and then Western) civilisation. They may be different, but not as different so as not to have certain similarities, even if as "distant relatives," in the European family.

To conclude I must mention that interculturalism is always closely related to education, because the attitudes and dispositions for intercultural exchange require not only rationality on the part of the actors, but also certain virtues that may not come naturally to everyone, the capacity to listen and learn from the other for instance. Another aspect essential to interculturalism as the engine that propels the construction of political identity is its capacity to harmonise unity and diversity, which has been developed by Beuchot's "analogical hermeneutics" to suggest an analogical cultural pluralism, which again for lack of time I will have to leave for another occasion.

Interculturalism, together with other factors, can contribute to the "making of Europeans," with an identity that respects and cherishes national diversity, but that provides too the minimum of unity necessary for the European polity to survive.

\section{Sources}

Armitstead, Louise. "Eurozone Is 'Unsustainable' Warns Mario Draghi." The Telegraph (2012), 


\section{Now Let Us Make Europeans}

http://www.telegraph.co.uk/finance/financialcrisis/9304027/Eurozoneis-unsustainable-warns-Mario-Draghi.html.

Beuchot, Mauricio. Interculturalidad Y Derechos Humanos, Filosofía. México, D. F.: Universidad Nacional Autónoma de México; Siglo XXI, 2005. "Catálogo De Las Lenguas Indígenas Nacionales." Instituto Nacional de las Lenguas Indígenas (INALI), http://www.inali.gob.mx/clin-inali/\#agr. "The Choice." The Economist,no.26 May 2012 (2012), http://www.economist.com/node/21555916.

"Cutting up Rough." The Economist (2012), http://www.economist.com/node/21555923.

d'Azeglio, Massimo. "I Miei Ricordi ", ed Einaudi.

Donati, Pierpaolo. "Beyond the Dilemmas of Multiculturalism: Recognition through 'Relational Reason'." International Review of Sociology 19, no. 1 (2009): 55-82.

"An Ever-Deeper Democratic Deficit." The Economist (2012), http://www.economist.com/node/21555927.

Flock, Elizabeth. "Angela Merkel Depicted as Nazi in Greece, as Anti-German Sentiment Grows." The Washington Post (2012), http://www.washingtonpost.com/blogs/blogpost/post/angela-merkeldepicted-as-nazi-in-greece-as-anti-german-sentimentgrows/2012/02/10/gIQASbZP4Q blog.html.

Guardia, Anton La. "The Ailing Euro." Diplomaatia,no. June 2012 (2012), http://www.diplomaatia.ee/index.php?id=242\&L=1\&TX ttnews[tt news

l=1428\&tx ttnews[backPid] $=606 \&$ cHash $=2585 \mathrm{e} 667 \mathrm{a} 0$.

Jiménez Lobeira, Pablo C. "Normative Conceptions of European Identity - a Synthetic Approach." Australian Journal of Professional and Applied Ethics 12, no. 1 \& 2 (2010): 159-70.

Jiménez Lobeira, Pablo Cristóbal. "EU Analogical Identity - or the Ties That Link (without Binding)." Australia National University Centre for European Studies Briefing Paper Series 1, no. 2 (2010).

Jiménez Lobeira, Pablo Cristóbal. "EU Citizenship and Political Identity: The Demos and Telos Problems." European Law Journal 18, no. 4 (2012).

Jiménez Lobeira, Pablo Cristóbal. "Exploring Cosmopolitan Communitarianist EU Citizenship - an Analogical Reading." Open Insight: Revista de Filosofía 2, no. 2 (2011): 145-68.

Jiménez Lobeira, Pablo Cristóbal. "Is Europe Still Worth Fighting For? Allegiance, Identity, and Integration Paradigms Revisited." CUP, Forthcoming.

Jiménez Lobeira, Pablo Cristóbal. "Liberal Democracy: Culture Free? The Habermas-Ratzinger Debate and Its Implications for Europe." Australian \& New Zealand Journal of European Studies Volume 2, No 2

/ Volume 3, No 1., no. May/June 2011 (2011): 44-57. 


\section{Citizenship, Solidarity and Identity}

Jiménez Lobeira, Pablo Cristóbal. "Veils, Crucifixes and Public Sphere: What Kind of Secularism? Rethinking Neutrality in a Post-Secular Europe."

(Forthcoming).

Krastev, Ivan. "How Real Is the Risk of Disintegration? The Lessons of the Soviet Collapse." Diplomaatia (2012), http://www.diplomaatia.ee/index.php?id=242\&L=1\&TX ttnews[tt news] $=142$ 6\&tx ttnews[backPid] $=606 \&$ cHash $=540 \mathrm{E} 9 \mathrm{~B} 202 \mathrm{~A}$.

Kulish, Nicholas. "Germany Looks to Its Own Costly Reunification in Resisting Stimulus for Greece." The New York Times (2012),

http://www.nytimes.com/2012/05/26/world/europe/germanreunification-pains-inform-stance-on-greece.html?pagewanted=all.

Paul Krugman, Martin Hesse and Thomas Schulz. "'Right Now, We Need Expansion'."

Spiegel Online

(2012),

http://www.spiegel.de/international/business/interview-witheconomist-paul-krugman-on-euro-zone-rescue-efforts-a-834566.html.

Pinard, Maxime. "L'europe, Ce Géant En Mal D'identité." Le Monde (2012), http://www.lemonde.fr/idees/article/2012/05/16/l-europe-ce-geant-enmal-d-identite 1701613 3232. HTml.

Pop, Valentina. "Italy Chastises Germany for Handling of Euro Crisis."

euobserver.com (2012), http://euobserver.com/19/116443.

Strupczewski, Jan. "EU Calls for Euro Zone Banking Union, Direct Bank Recapitalisations." Reuters (2012), http://uk.reuters.com/article/2012/05/30/uk-eu-economy-eurozoneidUKBRE84TOKF20120530.

Strupczewski, Marc Jones and Jan. "Ecb, EU Officials Warn Euro's Survival at Risk." Reuters (2012), http://www.reuters.com/article/2012/06/01/useurozone-inflation-idUSBRE84U0E320120601.

Vinocur, John. "Merkel's Stubborn March of Folly." The New York Times (2012),

http://www.nytimes.com/2012/05/29/opinion/merkelsstubborn-march-of-folly.html.

White, Michael. "European Debt Crisis: Better Merkozy Than Bismarck and Daladier." The Guardian (2012), http://www.guardian.co.uk/politics/blog/2011/Dec/05/european-debtcrisis-merkozy-bismarck.

\section{Notes}

${ }^{1}$ Centre for Applied Philosophy and Public Ethics, Charles Sturt University; Centre for European Studies, Australian National University. Canberra ACT Australia. 


\section{Now Let Us Make Europeans}

${ }^{2}$ Massimo d'Azeglio, "I Miei Ricordi ", ed Einaudi. http://www.letteraturaitaliana.net/pdf/Volume_8/t207.pdf.

${ }^{3}$ Ivan Krastev, "How Real Is the Risk of Disintegration? The Lessons of the Soviet Collapse," Diplomaatia(2012), http://www.diplomaatia.ee/index.php?id=242\&L=1\&tx_ttnews[tt_news]=1426\&tx_ttnews[b ackPid] $=606 \&$ cHash=540e9b202a.

${ }^{4}$ Valentina Pop, "Italy Chastises Germany for Handling of Euro Crisis," euobserver.com(2012), http://euobserver.сом/19/116443.

${ }^{5}$ d'Azeglio, "I Miei Ricordi ".

${ }^{6} \mathrm{NY}$ Times, "Germany looks to its own costly reunification..."

${ }^{7}$ Ibidem.

8 Marc Jones and Jan Strupczewski, "Ecb, EU Officials Warn Euro's Survival at Risk," Reuters(2012), http://www.reuters.com/article/2012/06/01/us-eurozone-inflation- idUSBRE84U0E320120601.

${ }^{9}$ The Economist, "Cutting up rough"

${ }^{10}$ Louise Armitstead, "Eurozone Is 'Unsustainable' Warns Mario Draghi," The Telegraph(2012),

http://www.telegraph.co.uk/finance/financialcrisis/9304027/Eurozone-is-unsustainablewarns-Mario-Draghi.html.

${ }^{11}$ Reuters, op. cit.

${ }^{12}$ Martin Hesse and Thomas Schulz Paul Krugman, "'Right Now, We Need Expansion'," Spiegel Online(2012),

http://www.spiegel.de/international/business/interview-with-economistpaul-krugman-on-euro-zone-rescue-efforts-a-834566.html.

13 "Cutting up Rough," The Economist(2012), http://www.economist.com/nodE/21555923.

${ }^{14}$ European Commission, "Council Recommendation on the implementation of the broad guidelines for the economic policies of the Member States whose currency is the euro"

15 "The Choice," The Economist, no. 26 May 2012 (2012),

http://www.economist.com/nodE/21555916.

${ }^{16}$ Ibid.

${ }^{17}$ The Economist, "How to save Spain," 2 June 2012.

${ }^{18}$ Valentina Pop, “Spain may speed up EU 'banking union'," EU Observer, 1 June 2012.

${ }^{19}$ Jan Strupczewski, "EU Calls for Euro Zone Banking Union, Direct Bank Recapitalisations," Reuters(2012), http://uk.reuters.com/article/2012/05/30/uk-eu-economy-eurozoneidUKBRE84T0KF20120530.

${ }^{20}$ European Commission, Communication from the Commision to the European Parliament, the European Council, the Council, the European Central Bank, the European Economic and Social Committee, the Committee of the Regions and the European Investment Bank, Action for Stability, Growth and Jobs," Brussels 30 May 2012.

${ }^{21}$ Michael White, "European Debt Crisis: Better Merkozy Than Bismarck and Daladier," The Guardian(2012), http://www.guardian.co.uk/politics/blog/2011/dec/05/european-debtcrisis-merkozy-bismarck.

${ }^{22}$ Elizabeth Flock, "Angela Merkel Depicted as Nazi in Greece, as Anti-German Sentiment Grows," The Washington Post(2012),

http://www.washingtonpost.com/blogs/blogpost/post/angela-merkel-depicted-as-nazi-in- 


\section{Citizenship, Solidarity and Identity}

greece-as-anti-german-sentiment-grows/2012/02/10/gIQASbZP4Q_blog.html.

${ }^{23}$ John Vinocur, "Merkel's Stubborn March of Folly," The New York Times(2012), http://www.nytimes.com/2012/05/29/opinion/merkels-stubborn-march-of-folly.html.

${ }^{24}$ Andrea Thomas, “Germany's Merkel Remains Popular Despite State Vote Defeat," The Wall Street Journal, 23 May 2012, http://online.wsj.com/article/BT-CO-20120523-703547.html

${ }^{25}$ Quentin Peel, “Angela's flashes," Diplomaatia 105, June 2012, http://www.diplomaatia.ee/index.php?id=606\&L=1

${ }^{26}$ Ibidem.

${ }^{27}$ The Economist, “An ever deeper democratic déficit," 26 May 2012.

${ }^{28}$ Ibidem.

${ }^{29}$ Ibid.

${ }^{30}$ Ibid.

31 "An Ever-Deeper Democratic Deficit," The Economist(2012), http://www.economist.com/node/21555927.

${ }^{32}$ Ibid.

${ }^{33}$ Pablo Cristóbal Jiménez Lobeira, "EU Citizenship and Political Identity: The Demos and Telos Problems," European Law Journal 18, no. 4 (2012).

${ }^{34}$ Pablo Cristóbal Jiménez Lobeira, "Is Europe Still Worth Fighting For? Allegiance, Identity, and Integration Paradigms Revisited," (CUP, Forthcoming).

${ }^{35}$ See: Pablo Cristóbal Jiménez Lobeira, "Liberal Democracy: Culture Free? The HabermasRatzinger Debate and Its Implications for Europe," Australian \& New Zealand Journal of European Studies Volume 2, No 2 / Volume 3, No 1., no. May/June 2011 (2011).

${ }^{36}$ Pablo Cristóbal Jiménez Lobeira, "EU Analogical Identity - or the Ties That Link (without Binding)," Australia National University Centre for European Studies Briefing Paper Series 1, no. 2 (2010).

${ }^{37}$ Pablo Cristóbal Jiménez Lobeira, "Veils, Crucifixes and Public Sphere: What Kind of Secularism? Rethinking Neutrality in a Post-Secular Europe," (Forthcoming).

${ }^{38}$ Anton La Guardia, "The Ailing Euro," Diplomaatia, no. June 2012 (2012), http://www.diplomaatia.ee/index.php?id=242\&L=1\&tx_ttnews[tt_news]=1428\&tx_ttnews[ backPid] $=606 \&$ cHash=2585e667a0.

${ }^{39}$ Anton La Guardia, “The ailing euro," Diplomaatia, June 2012, http://www.diplomaatia.ee/index.php?id=242\&L=1\&tx_ttnews[tt_news]=1428\&tx_ttnews[ backPid] $=606 \&$ cHash $=2585 \mathrm{e} 667 \mathrm{a} 0$

${ }^{40}$ Reported in: Nicholas Kulish, "Germany Looks to Its Own Costly Reunification in Resisting Stimulus for Greece," The New York Times(2012), http://www.nytimes.com/2012/05/26/world/europe/german-reunification-pains-informstance-on-greece.html?pagewanted=all.

${ }^{41}$ See for instance: Erich Follath and Jan Puhl, "Poland Emerges as a Central European Powerhouse," Der Spiegel, 25 May 2012.

${ }^{42}$ See: http://conventions.coe.int/treaty/en/Treaties/Html/005.htm 


\title{
Now Let Us Make Europeans
}

\author{
${ }^{43}$ See: http://eur- \\ lex.europa.eu/LexUriServ/LexUriServ.do?uri=OJ:C:2007:303:0001:0016:EN:PDF
}

${ }^{44}$ See an explanation of the problem in: Pablo Cristóbal Jiménez Lobeira, "Exploring Cosmopolitan Communitarianist EU Citizenship - an Analogical Reading," Open Insight: Revista de Filosofía 2, no. 2 (2011). And possible answers in: Pablo C Jiménez Lobeira, "Normative Conceptions of European Identity - a Synthetic Approach," Australian Journal of Professional and Applied Ethics 12, no. 1 \& 2 (2010).

${ }^{45}$ Maxime Pinard, "L'europe, Ce Géant En Mal D'identité," Le Monde(2012), http://www.lemonde.fr/idees/article/2012/05/16/l-europe-ce-geant-en-mal-didentite_1701613_3232.html. I thank Anne Webster for making me aware of this article.

${ }^{46}$ Krastev, "How Real Is the Risk of Disintegration? The Lessons of the Soviet Collapse."

${ }^{47}$ Pierpaolo Donati, "Beyond the Dilemmas of Multiculturalism: Recognition through 'Relational Reason'," International Review of Sociology 19, no. 1 (2009).

${ }^{48}$ Mauricio Beuchot, Interculturalidad Y Derechos Humanos, Filosofía (México, D. F.: Universidad Nacional Autónoma de México; Siglo XXI, 2005).

${ }^{49}$ Mexico for example recognises, besides Spanish, more than 60 other languages, come from Aztecs, Mayans and other peoples, and used by their descendants in everyday life. Nahuatl, for instance, the language spoken by the Aztecs and preserved through the Conquest thanks to the work of Spanish missionaries that put this and other languages into writing, is spoken by over 4 million people. See: "Catálogo De Las Lenguas Indígenas Nacionales," Instituto Nacional de las Lenguas Indígenas (INALI), http://www.inali.gob.mx/clin-inali/\#agr. 